\title{
Endocannabinoid turnover in GtoPdb v.2021.3
}

\author{
Stephen P.H. Alexander ${ }^{1}$, Patrick Doherty ${ }^{2}$, Christopher J. Fowler ${ }^{3}$, Jürg Gertsch ${ }^{4}$ and Mario van der
} Stelt ${ }^{5}$

1. University of Nottingham, UK

2. King's College London, UK

3. University Hospital of Umeå, Sweden

4. University of Bern, Switzerland

5. Leiden University, The Netherlands

\begin{abstract}
The principle endocannabinoids are 2-acylglycerol esters, such as 2-arachidonoylglycerol (2-AG), and $N$-acylethanolamines, such as anandamide ( $N$-arachidonoylethanolamine, AEA). The glycerol esters and ethanolamides are synthesised and hydrolysed by parallel, independent pathways. Mechanisms for release and re-uptake of endocannabinoids are unclear, although potent and selective inhibitors of facilitated diffusion of endocannabinoids across cell membranes have been developed [28]. FABP5 (Q01469) has been suggested to act as a canonical intracellular endocannabinoid transporter in vivo [17]. For the generation of 2-arachidonoylglycerol, the key enzyme involved is diacylglycerol lipase (DAGL), whilst several routes for anandamide synthesis have been described, the best characterized of which involves $N$-acylphosphatidylethanolamine-phospholipase D (NAPE-PLD, [70]). A transacylation enzyme which forms $N$-acylphosphatidylethanolamines has been identified as a cytosolic enzyme, PLA2G4E (Q3MJ16) [62]. In vitro experiments indicate that the endocannabinoids are also substrates for oxidative metabolism via cyclooxygenase, lipoxygenase and cytochrome P450 enzyme activities [5, 23, 72].
\end{abstract}

\section{Contents}

This is a citation summary for Endocannabinoid turnover in the Guide to Pharmacology database (GtoPdb). It exists purely as an adjunct to the database to facilitate the recognition of citations to and from the database by citation analyzers. Readers will almost certainly want to visit the relevant sections of the database which are given here under database links.

GtoPdb is an expert-driven guide to pharmacological targets and the substances that act on them. GtoPdb is a reference work which is most usefully represented as an on-line database. As in any publication this work should be appropriately cited, and the papers it cites should also be recognized. This document provides a citation for the relevant parts of the database, and also provides a reference list for the research cited by those parts. For further details see [12].

Please note that the database version for the citations given in GtoPdb are to the most recent preceding version in which the family or its subfamilies and targets were substantially changed. The links below are to the current version. If you need to consult the cited version, rather than the most recent version, please contact the GtoPdb curators.

\section{Database links}

Endocannabinoid turnover

https://www.guidetopharmacology.org/GRAC/FamilyDisplayForward?familyId=943

$N$-Acylethanolamine turnover

https://www.guidetopharmacology.org/GRAC/FamilyDisplayForward?familyId=273

Enzymes

NAPE-PLD( $N$-Acylphosphatidylethanolamine-phospholipase D)

https://www.guidetopharmacology.org/GRAC/ObjectDisplayForward?objectId=1398

FAAH(Fatty acid amide hydrolase)

https://www.guidetopharmacology.org/GRAC/ObjectDisplayForward?objectId=1400 
FAAH2(Fatty acid amide hydrolase-2)

https://www.guidetopharmacology.org/GRAC/ObjectDisplayForward?objectId=1401

$\operatorname{NAAA}(N$-Acylethanolamine acid amidase)

https://www.guidetopharmacology.org/GRAC/ObjectDisplayForward?objectId=1402

2-Acylglycerol ester turnover

https://www.guidetopharmacology.org/GRAC/FamilyDisplayForward?familyId=944

Enzymes

DAGL $\alpha($ Diacylglycerol lipase $\alpha)$

https://www.guidetopharmacology.org/GRAC/ObjectDisplayForward?objectId=1396

DAGL $\beta$ (Diacylglycerol lipase $\beta$ )

https://www.guidetopharmacology.org/GRAC/ObjectDisplayForward?objectId=1397

MAGL(Monoacylglycerol lipase)

https://www.guidetopharmacology.org/GRAC/ObjectDisplayForward?objectId=1399

ABHD2 ( $\alpha \beta$-Hydrolase 2)

https://www.guidetopharmacology.org/GRAC/ObjectDisplayForward?objectId=3147

ABHD6( $\alpha \beta$-Hydrolase 6)

https://www.guidetopharmacology.org/GRAC/ObjectDisplayForward?objectId=2919

ABHD12( $\alpha \beta$-Hydrolase 12)

https://www.guidetopharmacology.org/GRAC/ObjectDisplayForward?objectId=3070

\section{References}

1. Aaltonen N, Savinainen JR, Ribas CR, Rönkkö J, Kuusisto A, Korhonen J, Navia-Paldanius D, Häyrinen J, Takabe P and Käsnänen H et al.. (2013) Piperazine and piperidine triazole ureas as ultrapotent and highly selective inhibitors of monoacylglycerol lipase. Chem Biol 20: 379-90 [PMID:23521796]

2. Aggarwal G, Zarrow JE, Mashhadi Z, Flynn CR, Vinson P, Weaver CD and Davies SS. (2020) Symmetrically substituted dichlorophenes inhibit $N$-acyl-phosphatidylethanolamine phospholipase D. J Biol Chem 295: 7289-7300 [PMID:32284327]

3. Ahn K, Johnson DS, Fitzgerald LR, Liimatta M, Arendse A, Stevenson T, Lund ET, Nugent RA, Nomanbhoy TK and Alexander JP et al.. (2007) Novel mechanistic class of fatty acid amide hydrolase inhibitors with remarkable selectivity. Biochemistry 46: 13019-30 [PMID:17949010]

4. Ahn K, Johnson DS, Mileni M, Beidler D, Long JZ, McKinney MK, Weerapana E, Sadagopan N, Liimatta M and Smith SE et al.. (2009) Discovery and characterization of a highly selective FAAH inhibitor that reduces inflammatory pain. Chem Biol 16: 411-20 [PMID:19389627]

5. Alexander SP and Kendall DA. (2007) The complications of promiscuity: endocannabinoid action and metabolism. Br J Pharmacol 152: 602-23 [PMID:17876303]

6. Bachovchin DA, Ji T, Li W, Simon GM, Blankman JL, Adibekian A, Hoover H, Niessen S and Cravatt BF. (2010) Superfamily-wide portrait of serine hydrolase inhibition achieved by libraryversus-library screening. Proc Natl Acad Sci USA 107: 20941-6 [PMID:21084632]

7. Baggelaar MP, Chameau PJ, Kantae V, Hummel J, Hsu KL, Janssen F, van der Wel T, Soethoudt M, Deng H and den Dulk H et al.. (2015) Highly Selective, Reversible Inhibitor Identified by Comparative Chemoproteomics Modulates Diacylglycerol Lipase Activity in Neurons. J Am Chem Soc 137: 8851-7 [PMID:26083464]

8. Baggelaar MP, Maccarrone M and van der Stelt M. (2018) 2-Arachidonoylglycerol: A signaling lipid with manifold actions in the brain. Prog Lipid Res 71: 1-17 [PMID:29751000]

9. Bisogno T, Howell F, Williams G, Minassi A, Cascio MG, Ligresti A, Matias I, Schiano-Moriello A, Paul P and Williams EJ et al.. (2003) Cloning of the first sn1-DAG lipases points to the spatial and temporal regulation of endocannabinoid signaling in the brain. J Cell Biol 163: 463-8 [PMID:14610053]

10. Blankman JL, Long JZ, Trauger SA, Siuzdak G and Cravatt BF. (2013) ABHD12 controls brain lysophosphatidylserine pathways that are deregulated in a murine model of the neurodegenerative disease PHARC. Proc Natl Acad Sci USA 110: 1500-5 [PMID:23297193]

11. Blankman JL, Simon GM and Cravatt BF. (2007) A comprehensive profile of brain enzymes that hydrolyze the endocannabinoid 2-arachidonoylglycerol. Chem Biol 14: 1347-56 [PMID:18096503]

12. Buneman P, Christie G, Davies JA, Dimitrellou R, Harding SD, Pawson AJ, Sharman JL and Wu Y. (2020) Why data citation isn't working, and what to do about it Database 2020 [PMID:32367113]

13. Bühler KM, Huertas E, Echeverry-Alzate V, Giné E, Moltó E, Montoliu L and López-Moreno JA. (2014) Risky alcohol consumption in young people is associated with the fatty acid amide hydrolase gene polymorphism C385A and affective rating of drug pictures. Mol Genet Genomics 289: 279-89 [PMID:24407958]

14. Cajanus K, Holmström EJ, Wessman M, Anttila V, Kaunisto MA and Kalso E. (2016) Effect of endocannabinoid degradation on pain: role of FAAH polymorphisms in experimental and postoperative pain in women treated for breast cancer. Pain 157: 361-9 [PMID:26808012] 
15. Castellani B, Diamanti E, Pizzirani D, Tardia P, Maccesi M, Realini N, Magotti P, Garau G, Bakkum T and Rivara S et al.. (2017) Synthesis and characterization of the first inhibitor of Nacylphosphatidylethanolamine phospholipase D (NAPE-PLD). Chem Commun (Camb.) 53: 12814-12817 [PMID:29143042]

16. Chang JW, Niphakis MJ, Lum KM, Cognetta 3rd AB, Wang C, Matthews ML, Niessen S, Buczynski MW, Parsons LH and Cravatt BF. (2012) Highly selective inhibitors of monoacylglycerol lipase bearing a reactive group that is bioisosteric with endocannabinoid substrates. Chem Biol 19: 579-88 [PMID:22542104]

17. Chicca A, Nicolussi S, Bartholomäus R, Blunder M, Aparisi Rey A, Petrucci V, Reynoso-Moreno IDC, Viveros-Paredes JM, Dalghi Gens M and Lutz B et al.. (2017) Chemical probes to potently and selectively inhibit endocannabinoid cellular reuptake. Proc Natl Acad Sci USA 114: E5006E5015 [PMID:28584105]

18. Cisar JS, Weber OD, Clapper JR, Blankman JL, Henry CL, Simon GM, Alexander JP, Jones TK, Ezekowitz RAB and O'Neill GP et al.. (2018) Identification of ABX-1431, a Selective Inhibitor of Monoacylglycerol Lipase and Clinical Candidate for Treatment of Neurological Disorders. J Med Chem 61: 9062-9084 [PMID:30067909]

19. Cravatt BF, Demarest K, Patricelli MP, Bracey MH, Giang DK, Martin BR and Lichtman AH. (2001) Supersensitivity to anandamide and enhanced endogenous cannabinoid signaling in mice lacking fatty acid amide hydrolase. Proc Natl Acad Sci USA 98: 9371-6 [PMID:11470906]

20. Deng H, Kooijman S, van den Nieuwendijk AM, Ogasawara D, van der Wel T, van Dalen F, Baggelaar MP, Janssen FJ, van den Berg RJ and den Dulk H et al.. (2017) Triazole Ureas Act as Diacylglycerol Lipase Inhibitors and Prevent Fasting-Induced Refeeding. J Med Chem 60: 428440 [PMID:27992221]

21. Fiskerstrand T, H'mida-Ben Brahim D, Johansson S, M'zahem A, Haukanes BI, Drouot N, Zimmermann J, Cole AJ, Vedeler C and Bredrup C et al.. (2010) Mutations in ABHD12 cause the neurodegenerative disease PHARC: An inborn error of endocannabinoid metabolism. Am J Hum Genet 87: 410-7 [PMID:20797687]

22. Fiskerstrand T, Knappskog P, Majewski J, Wanders RJ, Boman H and Bindoff LA. (2009) A novel Refsum-like disorder that maps to chromosome 20. Neurology 72: 20-7 [PMID:19005174]

23. Fowler CJ. (2007) The contribution of cyclooxygenase-2 to endocannabinoid metabolism and action. Br J Pharmacol 152: 594-601 [PMID:17618306]

24. Ghafouri N, Tiger G, Razdan RK, Mahadevan A, Pertwee RG, Martin BR and Fowler CJ. (2004) Inhibition of monoacylglycerol lipase and fatty acid amide hydrolase by analogues of 2arachidonoylglycerol. Br J Pharmacol 143: 774-84 [PMID:15492019]

25. Giang DK and Cravatt BF. (1997) Molecular characterization of human and mouse fatty acid amide hydrolases. Proc Natl Acad Sci USA 94: 2238-42 [PMID:9122178]

26. Gorelik A, Gebai A, Illes K, Piomelli D and Nagar B. (2018) Molecular mechanism of activation of the immunoregulatory amidase NAAA. Proc Natl Acad Sci USA 115: E10032-E10040 [PMID:30301806]

27. Habib AM, Okorokov AL, Hill MN, Bras JT, Lee MC, Li S, Gossage SJ, van Drimmelen M, Morena $\mathrm{M}$ and Houlden $\mathrm{H}$ et al.. (2019) Microdeletion in a FAAH pseudogene identified in a patient with high anandamide concentrations and pain insensitivity. Br J Anaesth 123: e249-e253 [PMID:30929760]

28. Haj-Dahmane S, Shen RY, Elmes MW, Studholme K, Kanjiya MP, Bogdan D, Thanos PK, Miyauchi JT, Tsirka SE and Deutsch DG et al.. (2018) Fatty-acid-binding protein 5 controls retrograde endocannabinoid signaling at central glutamate synapses. Proc Natl Acad Sci USA 115: 3482-3487 [PMID:29531087]

29. Hammock B and Kodani S. (2017) Inhibitors for soluble epoxide hydrolase (seh) and fatty acid amide hydrolase (faah) Patent number: WO2017160861A1.

30. Hoover HS, Blankman JL, Niessen S and Cravatt BF. (2008) Selectivity of inhibitors of endocannabinoid biosynthesis evaluated by activity-based protein profiling. Bioorg Med Chem Lett 18: 5838-41 [PMID:18657971]

31. Hsu KL, Tsuboi K, Adibekian A, Pugh H, Masuda K and Cravatt BF. (2012) DAGLß inhibition perturbs a lipid network involved in macrophage inflammatory responses. Nat Chem Biol 8: 9991007 [PMID:23103940]

32. Johnson DS, Stiff C, Lazerwith SE, Kesten SR, Fay LK, Morris M, Beidler D, Liimatta MB, Smith SE and Dudley DT et al.. (2011) Discovery of PF-04457845: A Highly Potent, Orally Bioavailable, and Selective Urea FAAH Inhibitor. ACS Med Chem Lett 2: 91-96 [PMID:21666860]

33. Johnston M, Bhatt SR, Sikka S, Mercier RW, West JM, Makriyannis A, Gatley SJ and Duclos Jr RI. (2012) Assay and inhibition of diacylglycerol lipase activity. Bioorg Med Chem Lett 22: 4585-92 [PMID:22738638]

34. Kamat SS, Camara K, Parsons WH, Chen DH, Dix MM, Bird TD, Howell AR and Cravatt BF. (2015) Immunomodulatory lysophosphatidylserines are regulated by ABHD16A and ABHD12 interplay. Nat Chem Biol 11: 164-71 [PMID:25580854]

35. Karbarz MJ, Luo L, Chang L, Tham CS, Palmer JA, Wilson SJ, Wennerholm ML, Brown SM, Scott BP and Apodaca RL et al.. (2009) Biochemical and biological properties of 4-(3-phenyl-[1,2,4] 
thiadiazol-5-yl)-piperazine-1-carboxylic acid phenylamide, a mechanism-based inhibitor of fatty acid amide hydrolase. Anesth Analg 108: 316-29 [PMID:19095868]

36. Keith JM, Apodaca R, Tichenor M, Xiao W, Jones W, Pierce J, Seierstad M, Palmer J, Webb M and Karbarz M et al.. (2012) Aryl Piperazinyl Ureas as Inhibitors of Fatty Acid Amide Hydrolase (FAAH) in Rat, Dog, and Primate. ACS Med Chem Lett 3: 823-7 [PMID:24900385]

37. Keith JM, Apodaca R, Xiao W, Seierstad M, Pattabiraman K, Wu J, Webb M, Karbarz MJ, Brown S and Wilson S et al.. (2008) Thiadiazolopiperazinyl ureas as inhibitors of fatty acid amide hydrolase. Bioorg Med Chem Lett 18: 4838-43 [PMID:18693015]

38. Keith JM and Liu J. (2011) Modulators of fatty acid amide hydrolase. Patent number: WO2011139951 A1.

39. Kiss LE et al.. (2010) Pharmaceutical compounds. Patent number: WO2010074588 A2.

40. Kiss LE, Ferreira HS, Beliaev A, Torrao L and Bonafacio MJ Learmonth DA.. (2011) Design, synthesis, and structure-activity relationships of 1,3,4-oxadiazol-2(3H)-ones as novel FAAH inhibitors. Medchemcomm 2: 889-894

41. Knight MA, Hernandez D, Diede SJ, Dauwerse HG, Rafferty I, van de Leemput J, Forrest SM, Gardner RJ, Storey E and van Ommen GJ et al.. (2008) A duplication at chromosome 11q12.211 q12.3 is associated with spinocerebellar ataxia type 20. Hum Mol Genet 17: 3847-53 [PMID:18801880]

42. Kodani SD, Wan D, Wagner KM, Hwang SH, Morisseau C and Hammock BD. (2018) Design and Potency of Dual Soluble Epoxide Hydrolase/Fatty Acid Amide Hydrolase Inhibitors. ACS Omega 3: 14076-14086 [PMID:30411058]

43. Li W, Blankman JL and Cravatt BF. (2007) A functional proteomic strategy to discover inhibitors for uncharacterized hydrolases. J Am Chem Soc 129: 9594-5 [PMID:17629278]

44. Li Y, Chen Q, Yang L, Li Y, Zhang Y, Qiu Y, Ren J and Lu C. (2017) Identification of highly potent $\mathrm{N}$-acylethanolamine acid amidase (NAAA) inhibitors: Optimization of the terminal phenyl moiety of oxazolidone derivatives. Eur J Med Chem 139: 214-221 [PMID:28802121]

45. Li Y, Zhou P, Chen H, Chen Q, Kuang X, Lu C, Ren J and Qiu Y. (2018) Inflammation-restricted anti-inflammatory activities of a N-acylethanolamine acid amidase (NAAA) inhibitor F215. Pharmacol Res 132: 7-14 [PMID:29572189]

46. Lim ET, Raychaudhuri S, Sanders SJ, Stevens C, Sabo A, MacArthur DG, Neale BM, Kirby A, Ruderfer DM and Fromer M et al.. (2013) Rare complete knockouts in humans: population distribution and significant role in autism spectrum disorders. Neuron 77: 235-42 [PMID:23352160]

47. Liu Q, Tonai T and Ueda N. (2002) Activation of N-acylethanolamine-releasing phospholipase D by polyamines. Chem Phys Lipids 115: 77-84 [PMID:12047899]

48. Long JZ, Li W, Booker L, Burston JJ, Kinsey SG, Schlosburg JE, Pavón FJ, Serrano AM, Selley DE and Parsons LH et al.. (2009) Selective blockade of 2-arachidonoylglycerol hydrolysis produces cannabinoid behavioral effects. Nat Chem Biol 5: 37-44 [PMID:19029917]

49. Long JZ, Nomura DK, Vann RE, Walentiny DM, Booker L, Jin X, Burston JJ, Sim-Selley LJ, Lichtman AH and Wiley JL et al.. (2009) Dual blockade of FAAH and MAGL identifies behavioral processes regulated by endocannabinoid crosstalk in vivo. Proc Natl Acad Sci USA 106: 20270-5 [PMID:19918051]

50. M NK, V B S C T, G K V, B CS, Guntupalli S and J S B. (2016) Molecular characterization of human ABHD2 as TAG lipase and ester hydrolase. Biosci Rep 36 [PMID:27247428]

51. Migliore M, Habrant D, Sasso O, Albani C, Bertozzi SM, Armirotti A, Piomelli D and Scarpelli R. (2016) Potent multitarget FAAH-COX inhibitors: Design and structure-activity relationship studies. Eur J Med Chem 109: 216-37 [PMID:26774927]

52. Migliore M, Pontis S, Fuentes de Arriba AL, Realini N, Torrente E, Armirotti A, Romeo E, Di Martino S, Russo D and Pizzirani D et al.. (2016) Second-Generation Non-Covalent NAAA Inhibitors are Protective in a Model of Multiple Sclerosis. Angew Chem Int Ed Engl 55: 11193-7 [PMID:27404798]

53. Miller MR, Mannowetz N, Iavarone AT, Safavi R, Gracheva EO, Smith JF, Hill RZ, Bautista DM, Kirichok Y and Lishko PV. (2016) Unconventional endocannabinoid signaling governs sperm activation via the sex hormone progesterone. Science 352: 555-9 [PMID:26989199]

54. Mock ED, Mustafa M, Gunduz-Cinar O, Cinar R, Petrie GN, Kantae V, Di X, Ogasawara D, Varga ZV and Paloczi J et al.. (2020) Discovery of a NAPE-PLD inhibitor that modulates emotional behavior in mice. Nat Chem Biol 16: 667-675 [PMID:32393901]

55. Navia-Paldanius D, Savinainen JR and Laitinen JT. (2012) Biochemical and pharmacological characterization of human $\alpha / \beta$-hydrolase domain containing 6 (ABHD6) and 12 (ABHD12). J Lipid Res 53: 2413-24 [PMID:22969151]

56. Niphakis MJ, Cognetta 3rd AB, Chang JW, Buczynski MW, Parsons LH, Byrne F, Burston JJ, Chapman V and Cravatt BF. (2013) Evaluation of NHS carbamates as a potent and selective class of endocannabinoid hydrolase inhibitors. ACS Chem Neurosci 4: 1322-32 [PMID:23731016]

57. Nishiguchi KM, Avila-Fernandez A, van Huet RA, Corton M, Pérez-Carro R, Martín-Garrido E, 
López-Molina MI, Blanco-Kelly F, Hoefsloot LH and van Zelst-Stams WA et al.. (2014) Exome sequencing extends the phenotypic spectrum for ABHD12 mutations: from syndromic to nonsyndromic retinal degeneration. Ophthalmology 121: 1620-7 [PMID:24697911]

58. Nuzzi A, Fiasella A, Ortega JA, Pagliuca C, Ponzano S, Pizzirani D, Bertozzi SM, Ottonello G, Tarozzo G and Reggiani A et al.. (2016) Potent $\alpha$-amino- $\beta$-lactam carbamic acid ester as NAAA inhibitors. Synthesis and structure-activity relationship (SAR) studies. Eur J Med Chem 111: 138-59 [PMID:26866968]

59. Ogasawara D, Deng H, Viader A, Baggelaar MP, Breman A, den Dulk H, van den Nieuwendijk AM, van den Nieuwendijk AM, Soethoudt M and van der Wel T et al.. (2016) Rapid and profound rewiring of brain lipid signaling networks by acute diacylglycerol lipase inhibition. Proc Natl Acad Sci USA 113: 26-33 [PMID:26668358]

60. Ogasawara D, Ichu TA, Jing H, Hulce JJ, Reed A, Ulanovskaya OA and Cravatt BF. (2019) Discovery and Optimization of Selective and in Vivo Active Inhibitors of the Lysophosphatidylserine Lipase $\alpha / \beta$-Hydrolase Domain-Containing 12 (ABHD12). J Med Chem 62 : 1643-1656 [PMID:30720278]

61. Ogasawara D, Ichu TA, Vartabedian VF, Benthuysen J, Jing H, Reed A, Ulanovskaya OA, Hulce JJ, Roberts A and Brown S et al.. (2018) Selective blockade of the lyso-PS lipase ABHD12 stimulates immune responses in vivo. Nat Chem Biol 14: 1099-1108 [PMID:30420694]

62. Ogura Y, Parsons WH, Kamat SS and Cravatt BF. (2016) A calcium-dependent acyltransferase that produces N-acyl phosphatidylethanolamines. Nat Chem Biol 12: 669-71 [PMID:27399000]

63. Parkkari T, Haavikko R, Laitinen T, Navia-Paldanius D, Rytilahti R, Vaara M, Lehtonen M, Alakurtti S, Yli-Kauhaluoma J and Nevalainen T et al.. (2014) Discovery of triterpenoids as reversible inhibitors of $\alpha / \beta$-hydrolase domain containing 12 (ABHD12). PLoS ONE 9: e98286 [PMID:24879289]

64. Petersen G and Hansen HS. (1999) N-acylphosphatidylethanolamine-hydrolysing phospholipase D lacks the ability to transphosphatidylate. FEBS Lett 455: 41-4 [PMID:10428468]

65. Petrosino S, Campolo M, Impellizzeri D, Paterniti I, Allarà M, Gugliandolo E, D'Amico R, Siracusa R, Cordaro M and Esposito E et al.. (2017) 2-Pentadecyl-2-Oxazoline, the Oxazoline of Pea, Modulates Carrageenan-Induced Acute Inflammation. Front Pharmacol 8: 308 [PMID:28611664]

66. Piomelli D, Scalvini L, Fotio Y, Lodola A, Spadoni G, Tarzia G and Mor M. (2020) NAcylethanolamine Acid Amidase (NAAA): Structure, Function, and Inhibition. J Med Chem 63 : 7475-7490 [PMID:32191459]

67. Ribeiro A, Pontis S, Mengatto L, Armirotti A, Chiurchiù V, Capurro V, Fiasella A, Nuzzi A, Romeo E and Moreno-Sanz G et al.. (2015) A Potent Systemically Active N-Acylethanolamine Acid Amidase Inhibitor that Suppresses Inflammation and Human Macrophage Activation. ACS Chem Biol 10: 1838-46 [PMID:25874594]

68. Roughley S, Walls S, Hart T, Parsons R, Brough P, Graham C and Macias A. (2009) Azetidine derivatives. Patent number: WO2009109743 A1.

69. Savinainen JR, Saario SM and Laitinen JT. (2012) The serine hydrolases MAGL, ABHD6 and ABHD12 as guardians of 2-arachidonoylglycerol signalling through cannabinoid receptors. Acta Physiol (Oxf) 204: 267-76 [PMID:21418147]

70. Simon GM and Cravatt BF. (2010) Characterization of mice lacking candidate N-acyl ethanolamine biosynthetic enzymes provides evidence for multiple pathways that contribute to endocannabinoid production in vivo. Mol Biosyst 6: 1411-8 [PMID:20393650]

71. Sirrs S, van Karnebeek CD, Peng X, Shyr C, Tarailo-Graovac M, Mandal R, Testa D, Dubin D, Carbonetti G and Glynn SE et al.. (2015) Defects in fatty acid amide hydrolase 2 in a male with neurologic and psychiatric symptoms. Orphanet J Rare Dis 10: 38 [PMID:25885783]

72. Snider NT, Walker VJ and Hollenberg PF. (2010) Oxidation of the endogenous cannabinoid arachidonoyl ethanolamide by the cytochrome P450 monooxygenases: physiological and pharmacological implications. Pharmacol Rev 62: 136-54 [PMID:20133390]

73. Solorzano C, Zhu C, Battista N, Astarita G, Lodola A, Rivara S, Mor M, Russo R, Maccarrone M and Antonietti F et al.. (2009) Selective N-acylethanolamine-hydrolyzing acid amidase inhibition reveals a key role for endogenous palmitoylethanolamide in inflammation. Proc Natl Acad Sci USA 106: 20966-71 [PMID:19926854]

74. Tanaka M, Moran S, Wen J, Affram K, Chen T, Symes AJ and Zhang Y. (2017) WWL70 attenuates PGE2 production derived from 2-arachidonoylglycerol in microglia by ABHD6-independent mechanism. J Neuroinflammation 14: 7 [PMID:28086912]

75. Thorel MF, Krichevsky M and Lévy-Frébault VV. (1990) Numerical taxonomy of mycobactindependent mycobacteria, emended description of Mycobacterium avium, and description of Mycobacterium avium subsp. avium subsp. nov., Mycobacterium avium subsp. paratuberculosis subsp. nov., and Mycobacterium avium subsp. silvaticum subsp. nov. Int J Syst Bacteriol 40: 254-60 [PMID:2397193]

76. Tingaud-Sequeira A, Raldúa D, Lavie J, Mathieu G, Bordier M, Knoll-Gellida A, Rambeau P, Coupry I, André M and Malm E et al.. (2017) Functional validation of ABHD12 mutations in the neurodegenerative disease PHARC. Neurobiol Dis 98: 36-51 [PMID:27890673] 
77. Tsuboi K, Hilligsmann C, Vandevoorde S, Lambert DM and Ueda N. (2004) Ncyclohexanecarbonylpentadecylamine: a selective inhibitor of the acid amidase hydrolysing $\mathrm{N}$ acylethanolamines, as a tool to distinguish acid amidase from fatty acid amide hydrolase. Biochem J 379: 99-106 [PMID:14686878]

78. Tsuboi K, Ikematsu N, Uyama T, Deutsch DG, Tokumura A and Ueda N. (2013) Biosynthetic pathways of bioactive N-acylethanolamines in brain. CNS Neurol Disord Drug Targets 12: 7-16 [PMID:23394527]

79. Tuo W, Leleu-Chavain N, Spencer J, Sansook S, Millet R and Chavatte P. (2017) Therapeutic Potential of Fatty Acid Amide Hydrolase, Monoacylglycerol Lipase, and N-Acylethanolamine Acid Amidase Inhibitors. J Med Chem 60: 4-46 [PMID:27766867]

80. Ueda N, Yamanaka K and Yamamoto S. (2001) Purification and characterization of an acid amidase selective for N-palmitoylethanolamine, a putative endogenous anti-inflammatory substance. J Biol Chem 276: 35552-7 [PMID:11463796]

81. van Esbroeck ACM, Janssen APA, Cognetta 3rd AB, Ogasawara D, Shpak G, van der Kroeg M, Kantae V, Baggelaar MP, de Vrij FMS and Deng H et al.. (2017) Activity-based protein profiling reveals off-target proteins of the FAAH inhibitor BIA 10-2474. Science 356: 1084-1087 [PMID:28596366]

82. van Esbroeck ACM, Kantae V, Di X, van der Wel T, den Dulk H, Stevens AF, Singh S, Bakker AT, Florea BI and Stella N et al.. (2019) Identification of $\alpha, \beta$-Hydrolase Domain Containing Protein 6 as a Diacylglycerol Lipase in Neuro-2a Cells. Front Mol Neurosci 12: 286 [PMID:31849602]

83. Wan M, Cravatt BF, Ring HZ, Zhang X and Francke U. (1998) Conserved chromosomal location and genomic structure of human and mouse fatty-acid amide hydrolase genes and evaluation of clasper as a candidate neurological mutation. Genomics 54: 408-14 [PMID:9878243]

84. Watabiki T, Tsuji N, Kiso T, Ozawa T, Narazaki F and Kakimoto S. (2017) In vitro and in vivo pharmacological characterization of ASP8477: A novel highly selective fatty acid amide hydrolase inhibitor. Eur J Pharmacol 815: 42-48 [PMID:29017758]

85. Wei BQ, Mikkelsen TS, McKinney MK, Lander ES and Cravatt BF. (2006) A second fatty acid amide hydrolase with variable distribution among placental mammals. J Biol Chem 281: 3656978 [PMID:17015445]

86. Whibley AC, Plagnol V, Tarpey PS, Abidi F, Fullston T, Choma MK, Boucher CA, Shepherd L, Willatt L and Parkin G et al.. (2010) Fine-scale survey of X chromosome copy number variants and indels underlying intellectual disability. Am J Hum Genet 87: 173-88 [PMID:20655035]

87. Wyatt RM, Fraser I, Welty N, Lord B, Wennerholm M, Sutton S, Ameriks MK, Dugovic C, Yun S and White A et al.. (2020) Pharmacologic Characterization of JNJ-42226314, [1-(4-

Fluorophenyl)indol-5-yl]-[3-[4-(thiazole-2-carbonyl)piperazin-1-yl]azetidin-1-yl]methanone, a Reversible, Selective, and Potent Monoacylglycerol Lipase Inhibitor. J Pharmacol Exp Ther 372 : 339-353 [PMID:31818916]

88. Xie S, Borazjani A, Hatfield MJ, Edwards CC, Potter PM and Ross MK. (2010) Inactivation of lipid glyceryl ester metabolism in human THP1 monocytes/macrophages by activated organophosphorus insecticides: role of carboxylesterases 1 and 2. Chem Res Toxicol 23: 1890904 [PMID:21049984]

89. Zhi Z, Zhang W, Yao J, Shang Y, Hao Q, Liu Z, Ren Y, Li J, Zhang G and Wang J. (2020) Discovery of Aryl Formyl Piperidine Derivatives as Potent, Reversible, and Selective Monoacylglycerol Lipase Inhibitors. J Med Chem 63: 5783-5796 [PMID:32429662] 